\title{
Comparison of cephalometric craniofacial features and facial photographic features for two generations of patients
}

\author{
Nasim Mirdehghan*; Kanaan Sharif*; Ajit Kalia*; Masoud Mirdehghan*; Kazem Mirdehghan*; Najneen Noormohammed Khan* \\ * Department of Orthodontics and Dentofacial Orthopaedics, M.A. Rangoonwala College of Dental Sciences; Research Centre, Pune-1
}

\begin{abstract}
Aim of the study: To determine the correlation and variant heritability values of craniofacial variables between parents and their offspring. Materials and methods: The sample consisted 20 Indian families; each family consisted of father, mother, son, and daughter. Lateral cephalograms and facial photographs were taken for each member of the family. Measurements of Fifty -three angular, linear, and proportional cephalometric variables were taken and their photographic analysis was done. Interfamilial correlations and heritability (h2) values were estimated in pairings between father-son, father- daughter, mother-son, and mother-daughter.

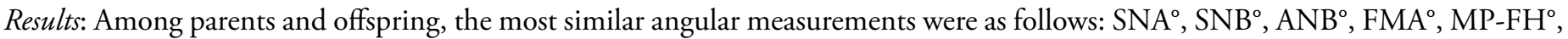
LI-NB ${ }^{\circ}, \mathrm{Op}-\mathrm{FH}^{\circ}, \mathrm{UI}_{-N{ }^{\circ}}, \mathrm{OP}_{-} \mathrm{SN}^{\circ}, \mathrm{LI}_{-N B}{ }^{\circ}$ and The most similar linear measurements were as follows: Co-Pt.A, Co-Gn, N- ANS, UI-A, Me-Me', LI-A.Pog, Mx 1 exposure. In the father-offspring, both the correlation coefficients as well as the heritable values were greater than the mother-offspring pairings.

Conclusions: The overall correlation and mean h2 values for the three types of measurements demonstrated greater values in the father-offspring groups as compared to the mother-offspring groups, with the father -son pairings more significant than the fatherdaughter groups.

N. Mirdehghan, K. Sharif, A. Kalia, M. Mirdehghan, K. Mirdehghan, N.N. Khan. Comparison of cephalometric craniofacial features and facial photographic features for two generations of patients. South Eur J Orthod Dentofac Res. 2020;7(2):22-31.
\end{abstract}

\section{INTRODUCTION}

Throughout the $20^{\text {th }}$ century, the role of genes and the environment to the etiology of malocclusion was a topic of debate. ${ }^{1}$ The role of genetic and environmental influences in orthodontic has been discussed mainly with respect to the etiology of malocclusions. ${ }^{2}$ orthodontic arena suggest that several genes are related to the etiology of malocclusion.

The etiology of malocclusion has found a strong influence of heredity/gene. The best known example of genetic influence on malocclusion is the famous "hapsburgs jaw"(prognathic mandible), which was the classical phenotype of European Royal ancestry.

Corresponding Author:

Nasim Mirdehghan

Department of Orthodontics and Dentofacial Orthopaedics,

M.A. Rangoonwala College of Dental Sciences; Research Centre, Pune-1 e-mail:drmsnasim@gmail.com
The role between genetic and environmental factors starts at birth and continues till the end of life. ${ }^{2}$ During embryonic craniofacial morphogenesis, genetic mechanisms evidently predominate, but environment is also thought to postnatal affect dentofacial morphology, especially during facial growth. ${ }^{1}$ Various studies have been undertaken on craniofacial relationships in twins that have provided valuable information on the role of heredity in malocclusion. ${ }^{3}$

A better understanding of the relative effects of genes and environment on dentofacial and occlusal parameters should enhance our knowledge of the etiology of orthodontic disorders, and the possibilities and limitations of orthodontic treatment and treatment planning. Studies comparing parents with children has been limited due to the fact that older generations' teeth decay, restorative, prosthetic, and orthodontic care makes such investigations challenging. ${ }^{4}$

Each malocclusion has its own characteristic slot in the genetic and environmental spectrum and hence, the diagnostic goal is to 
assess the relative contributions of genetics and the environment. For orthodontic intervention, the greater the genetic variable, the worse the prognosis for a positive result could be. ${ }^{3}$

Parental data is well known to be helpful in forecasting the craniofacial proportions and the child's facial growth. Therefore, it is of interest to establish a pattern of heritability between them. Because a limited number of studies on this matter have been conducted, it was the aim of this study to determine the influence of heredity of craniofacial form between parents and their offspring, and to correlate the similarity pattern between both among Indian families.

\section{MATERIALS AND METHODS}

The study was approved by ethics committee of M.A. Rangoonwala Dental College. Study materials consisted of eighty lateral cephalograms and facial photographs for twenty Indian families. Each family consisted of; father, mother, son and daughter. The families were chosen randomly according to the inclusion criteria which were 1) The ages of the children were 17 years of age or older. (Children in post pubertal growth spurt period, cervical vertebrae showing C5-C6 Baccetti calcification indicating completion of growth). 2) Permanent dentition stage for offspring. 3) All members of the family were blood relatives (neither adopted nor stepchildren). The exclusion criteria used for sample selection was as follows: 1) No extensive prosthetic treatment for parents (like complete denture). 2) No history of orthodontic treatment; no abnormal dental habits such as thumb sucking, mouth breathing, and no abnormal anatomical nasal constriction. 3) No congenital abnormalities such as cleft lip or palate or any craniofacial deformities. 4) No trauma.

Lateral cephalograms were taken using a digital $\mathrm{x}$ ray machine [Model: advapex, Company: panorraitic system, Printer: Fujifilms DRY PIX 7000]. For standardized positioning, a cephalostat was used for maintaining the subject's head in a constant relationship to the film. This will standardize the distance of the subject to the film, the $\mathrm{x}$-ray exposure as well as the magnification exposure. The lateral cephalometric radiographs of the patients were taken using $75 \mathrm{kVp}$ and $10 \mathrm{mAs}$ and exposure time of 0.9 second. All subjects were asked to sit upright and look straight forward into the image of their eyes in a small mirror located at the same level as the pupils of their eye, with a lead apron on their chests. Ear rods were placed into the ear canals in a comfortable position, and the orbital pointer was positioned accurately.

Facial photographs were taken with the use of SLR digital camera [Canon EOS 550D], two types of extra oral photographs were taken 1) Face-Frontal (lips relaxed) ${ }^{5}$ in which the subjects stood with their head in natural head position6 ,with eyes looking straight in to the camera lens. 'portrait' view were taken with the face filling the frame extending to just above the top of the head and just below the chin. Mirror of $-1000 \mathrm{~mm}$ x $200 \mathrm{~mm} \times 3 \mathrm{~mm}$ was Mounted on imaging room wall. By requesting subjects to look in to their own eyes, this is used to provide a visually guided registration of natural head position. 2) Profile photograph in which subjects were asked to bodily turn to their left, thus having a right profile side facing the operator. The subjects were asked to look forward in to the mirror and teeth in occlusion.

The same investigator traced all radiographs. Twenty-nine landmarks were identified (Figure 1) (Table 1). Recorded, and angular, linear, and proportional measurements were obtained (Figure 2a, b, c, 3a, b, c and 4) (Table 2, 3) displays the measurements. Both manual and digital tracing of each radiographs were carried out. Manual tracing was done in a dark room using an illuminated viewing screen with a black surrounding to reduce extraneous light. Each X-ray was firmly secured to the surface of a viewing box and was traced using a $0.35 \mathrm{~mm}$ lead pencil on an acetate matte tracing paper, 0.003 inch $\mathrm{x} 8$ inch $\mathrm{x} 10$ inch. Identification of landmarks was done by a single point. For bilateral structures and double images, the mid-point was chosen by construction. For digital tracing, the radiographs were scanned at a resolution of 300 dots per inch (dpi) using an Epson scanner (Epson Perfection V700 PHOTO) and then were digitized using a commercially available software (Dolphin Imaging 10.5 Premium). Landmark identification was carried out by manually dot tracing on the digital image using a mouse-driven curser in a predetermined sequence. The cephalometric measurements were then automatically calculated by the software. Error was assessed by using the Dahlberg method as well as the coefficient of reliability.

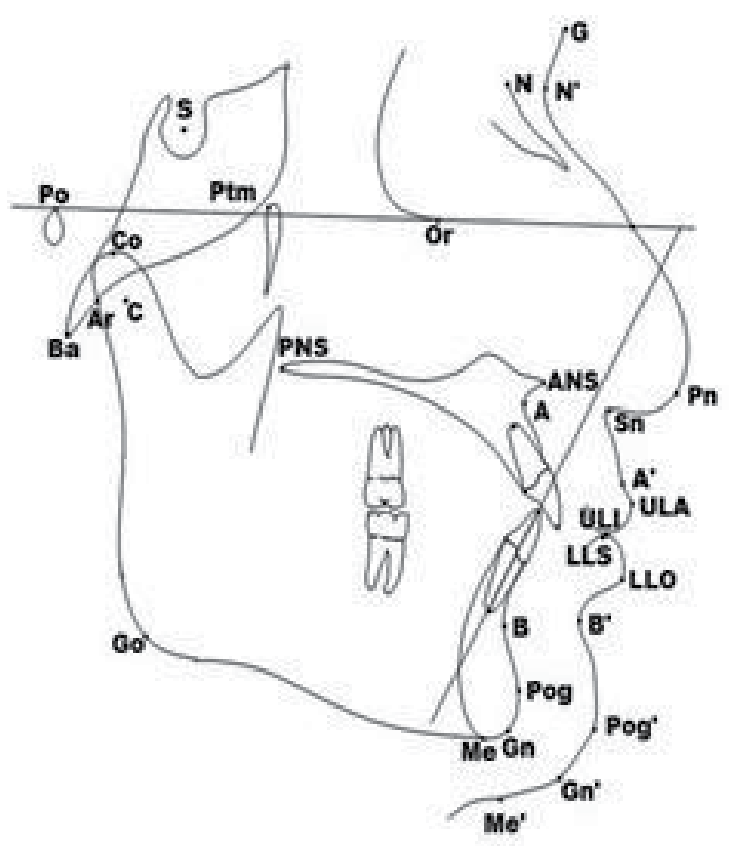

Figure 1. Cephalometric landmarks abbreviation and definitions. 
Table 1. Cephalometric landmarks abbreviation and definitions. (Jacobson and Jacobson 2006)

\begin{tabular}{|c|c|c|}
\hline Landmark & Abbreviation & Definition \\
\hline Sella & $S$ & The geometric center of the pituitary gland. \\
\hline Nasion & $\mathrm{N}$ & $\begin{array}{l}\text { The most anterior point on the frontonasal suture } \\
\text { in the midsagittal plane. }\end{array}$ \\
\hline Basion & $\mathrm{Ba}$ & $\begin{array}{l}\text { The lowest point on the anterior rim of the foramen } \\
\text { magnum. }\end{array}$ \\
\hline Porion & Po & The most superior point of the external auditory meatus. \\
\hline Orbitale & Or & The lowest point on the inferior rim of the orbit. \\
\hline Pterygomaxillare & Ptm & $\begin{array}{l}\text { The point where the pteygoid process of the sphenoid } \\
\text { bone and the pterygoid process of the maxilla begin to } \\
\text { form the pterygomaxillary fissure }\end{array}$ \\
\hline Subspinale & Point A & $\begin{array}{l}\text { The most posterior midline point in the concavity } \\
\text { between the ANS(the anterior tip of the sharp bony } \\
\text { process of the maxilla at the lower margin of the anterior } \\
\text { nasal opening) and the prosthion (the most inferior point } \\
\text { on the alveolar bone overlying the maxillary incisors). }\end{array}$ \\
\hline $\begin{array}{l}\text { Anterior Nasal } \\
\text { Spine }\end{array}$ & ANS & $\begin{array}{l}\text { The anterior tip of the sharp bony process of the maxilla } \\
\text { at the lower margin of the anterior nasal opening. }\end{array}$ \\
\hline $\begin{array}{l}\text { Posterior Nasal } \\
\text { Spine }\end{array}$ & PNS & $\begin{array}{l}\text { The posterior spine of the palatine bone constituting } \\
\text { the hard palate. }\end{array}$ \\
\hline Supramentale & Point B & $\begin{array}{l}\text { The most posterior midline point in the concavity } \\
\text { of the mandible between the most superior point on } \\
\text { the alveolar bone overlying the mandibular incisors } \\
\text { (infradental) and Pog. }\end{array}$ \\
\hline Pogonion & Pog & The most anterior point on the chin. \\
\hline Gnathion & Gn & $\begin{array}{l}\text { A point located by taking the midpoint between the } \\
\text { anterior (pogonion) and inferior (menton) points of the } \\
\text { bony chin. }\end{array}$ \\
\hline Menton & $\mathrm{Me}$ & $\begin{array}{l}\text { The most lowest point on the symphyseal shadow } \\
\text { of the mandible seen on a lateral cephalogram. }\end{array}$ \\
\hline Gonion & Go & $\begin{array}{l}\text { A point on the curvature of the angle of the mandible } \\
\text { located by bisecting the angle formed by lines tangent } \\
\text { to the posterior ramus and the inferior border of the } \\
\text { mandible. }\end{array}$ \\
\hline Articulare & $\mathrm{Ar}$ & $\begin{array}{l}\text { A point at the junction of the posterior border of the } \\
\text { ramus and the inferior border of the posterior cranial } \\
\text { base (occipital bone). }\end{array}$ \\
\hline Condylion & Co & $\begin{array}{l}\text { The most superior midline point on the condyle of the } \\
\text { mandible. }\end{array}$ \\
\hline $\begin{array}{l}\text { Apparent axis } \\
\text { of the condyle }\end{array}$ & $\mathrm{C}$ & $\begin{array}{l}\text { The center of the condyle, found by tracing the head } \\
\text { of the condyle and approximating its center). }\end{array}$ \\
\hline \multicolumn{3}{|c|}{ Soft tissue landmarks } \\
\hline Glabella & G & $\begin{array}{l}\text { The most prominent anterior point in the mid sagittal } \\
\text { plane of the forehead. }\end{array}$ \\
\hline Soft tissue nasion & $\mathrm{N}^{\prime}$ & $\begin{array}{l}\text { The point of greatest concavity in the midline between } \\
\text { forhead and the nose. }\end{array}$ \\
\hline $\begin{array}{l}\text { Tip of the nose } \\
\text { (Pronasale) }\end{array}$ & $P$ & The most anterior or prominent point of the nose. \\
\hline Subnasale & Sn & $\begin{array}{l}\text { The point at which the columella merges with the upper } \\
\text { lip in the midsagittal plane. }\end{array}$ \\
\hline $\begin{array}{l}\text { Soft tissue } \\
\text { point A }\end{array}$ & $A^{\prime}$ & $\begin{array}{l}\text { The point of greatest concavity in the midline of upper } \\
\text { lip between subnasale }\end{array}$ \\
\hline Upper lip anterior & ULA & The most anterior point of the upper lip. \\
\hline Upper lip inferior & ULI & The lower most point on the vermilion of upper lip. \\
\hline Lower lip superior & LLS & The upper most point on vermilion of lower lip. \\
\hline Lower lip outside & LLO & $\begin{array}{l}\text { The median point in the lower margin of the lower } \\
\text { membranous lip. }\end{array}$ \\
\hline Soft tissue point $B$ & $\mathrm{~B}^{\prime}$ & $\begin{array}{l}\text { The point of greatest concavity in the middle of the lower } \\
\text { lip between lower lip outside and soft tissue pogonion. }\end{array}$ \\
\hline Soft tissue pogonion & Pog' & The most anterior point on the chin. \\
\hline $\begin{array}{l}\text { Soft tissue } \\
\text { menton }\end{array}$ & $\mathrm{Me}^{\prime}$ & Lowest point on the contour of the soft tissue chin. \\
\hline
\end{tabular}

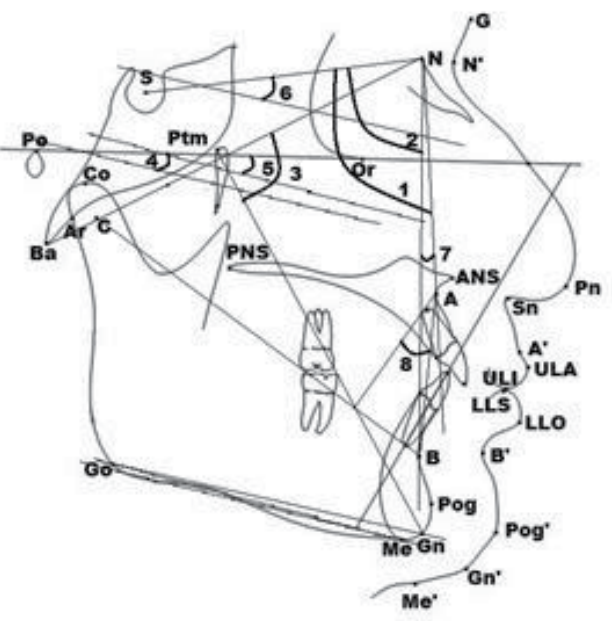

Figure 2a. Cephalometric skeletal angular measurements and definitions.

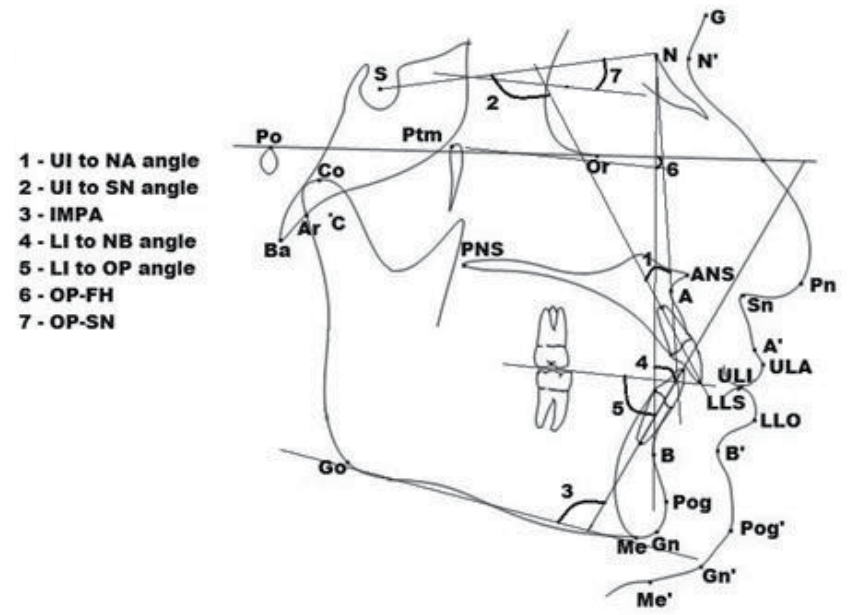

Figure 2b. Cephalometric dental angular measurements and their definitions.

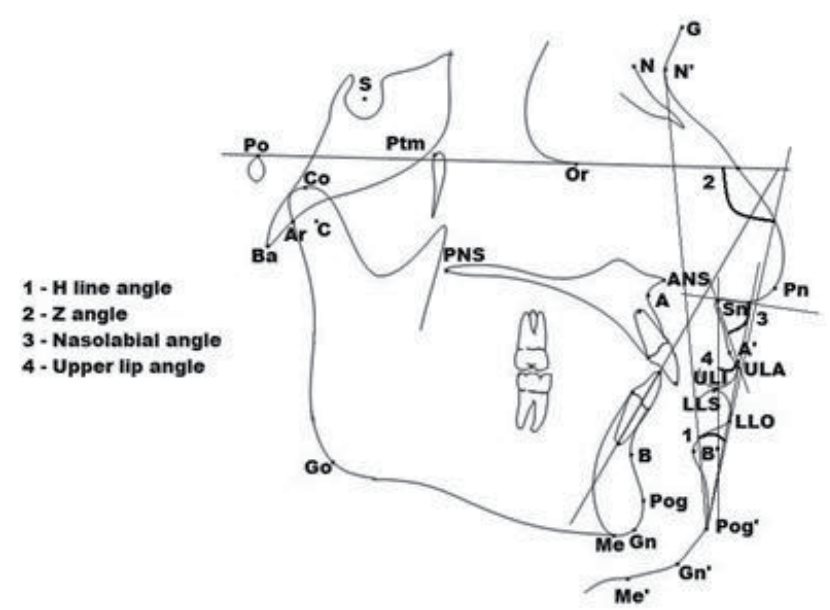

Figure 2c. Cephalometric soft tissue angular measurements and their definitions. 
Table 2. Cephalometric angular measurements and their definitions.

\begin{tabular}{|c|c|c|c|}
\hline & & Measurement & Definition \\
\hline \multirow{8}{*}{ 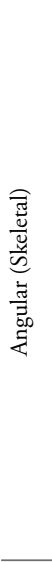 } & 1. & $\mathrm{SNA}^{0}$ & $\begin{array}{l}\text { Anteroposterior position of the maxilla relative to the cranial } \\
\text { base measured as the angle between S-N line and point A-N } \\
\text { line. }\end{array}$ \\
\hline & 2. & $\mathrm{SNB}^{0}$ & $\begin{array}{l}\text { Anteroposterior position of the mandible relative to the } \\
\text { cranial base measured as the angle between S-N line and } \\
\text { point B-N line. }\end{array}$ \\
\hline & 3. & $\mathrm{ANB}^{0}$ & Difference between angles SNA and SNB. \\
\hline & 4. & $\begin{array}{l}\text { FACIAL AXIS } \\
\text { ANGLE }\end{array}$ & $\begin{array}{l}\text { Angle between Ba-N and posterosuperior Ptm to constructed } \\
\text { Gn. }\end{array}$ \\
\hline & 5. & FMA & $\begin{array}{l}\text { Frankfort mandibular plane angle. This is angle between FH } \\
\text { and mandibular plane. }\end{array}$ \\
\hline & 6. & MP-SN ${ }^{0}$ & This is angle formed between $S N$ and Go-Gn. \\
\hline & 7. & MP-FH ${ }^{0}$ & This is angle formed beteen FH and Go-Me. \\
\hline & 8. & Beta angle $^{0}$ & $\begin{array}{l}\text { This is the angle from the line from point } A \text { perpendicular to } \\
\text { the } C-B \text { line and the } A-B \text { line. }\end{array}$ \\
\hline \multirow{7}{*}{ 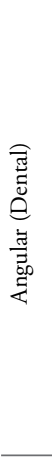 } & 9. & UI to $\mathrm{NA}^{0}$ & $\begin{array}{l}\text { Angle formed by intersection of long axis of upper incisor } \\
\text { with N-A. }\end{array}$ \\
\hline & 10. & UI to $\mathrm{S}-\mathrm{N}^{0}$ & $\begin{array}{l}\text { Angle formed by intersection of long axis of upper incisor } \\
\text { with S-N. }\end{array}$ \\
\hline & 11. & IMPA $^{0}$ & $\begin{array}{l}\text { Angle formed by the intersection of long axis of lower incisor } \\
\text { with mandibular plane. }\end{array}$ \\
\hline & 12. & $\mathrm{LI}$ to $\mathrm{NB}^{0}$ & $\begin{array}{l}\text { Angle formed by intersection of long axis of lower incisor } \\
\text { with NB. }\end{array}$ \\
\hline & 13. & $\mathrm{LI}$ to $\mathrm{OP}^{0}$ & $\begin{array}{l}\text { Angle formed by intersection of long axis of lower incisor } \\
\text { with occlusal plane. }\end{array}$ \\
\hline & 14. & OP-SN ${ }^{0}$ & The angle between occlusal plane and S-N. \\
\hline & 15. & ${\mathrm{OP}-\mathrm{FH}^{0}}^{0}$ & $\begin{array}{l}\text { The angle between occlusal plane and Frankfort horizontal } \\
\text { plane. }\end{array}$ \\
\hline \multirow{4}{*}{ 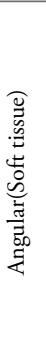 } & 16. & $\mathrm{H}$ line angle & $\begin{array}{l}\text { Harmony line is tangent to the chin point and the upper lip. } \\
\text { The H line angle is formed between this line ans soft tissue } \\
\text { nasion -pogonion line. }\end{array}$ \\
\hline & 17. & $\mathrm{Z}$ angle & $\begin{array}{l}\text { Angle formed by the intersection of Frankfort horizontal and } \\
\text { a line connecting soft tissue chin (pog') and most protrusive } \\
\text { lip point. }\end{array}$ \\
\hline & 18. & Nasolabial angle & $\begin{array}{l}\text { The angle is formed by two lines, a columella tangent and a } \\
\text { line from subnasale to upper lip anterior. }\end{array}$ \\
\hline & 19. & Upper lip angle & $\begin{array}{l}\text { The angle between the True Vertical Line (TVL) } \\
\text { (The line placed through subnasale and is perpendicular to } \\
\text { the natural horizontal head position) and most anterior part } \\
\text { of upper lip. }\end{array}$ \\
\hline
\end{tabular}

Descriptive analysis was calculated for each of the cephalometric measurements. A relation between the father and the sons and between the sons and the mother was determined for each variable. Comparison of daughters' variables with both the father and the mother was done. Calculations were performed using two statistical methods: the Pearson correlation coefficient and the heritability test. The formula of heritability between parents and offspring is twice the regression coefficient, $b$, of the offspring on the parent $18: \mathrm{h} 2=2 \mathrm{xb}$.

Heritability estimate values should be between 0 and 1 . For any trait, a heritability estimate of 1 is expressed theoretically with no environmental influence; on the other hand, an estimate of 0 defines the trait with no heritable influence. A midway value of 0.5 would have its variability influenced by both environment and genetics. However, heritability estimates may exceed the value of 1 because in humans, the method used for estimating

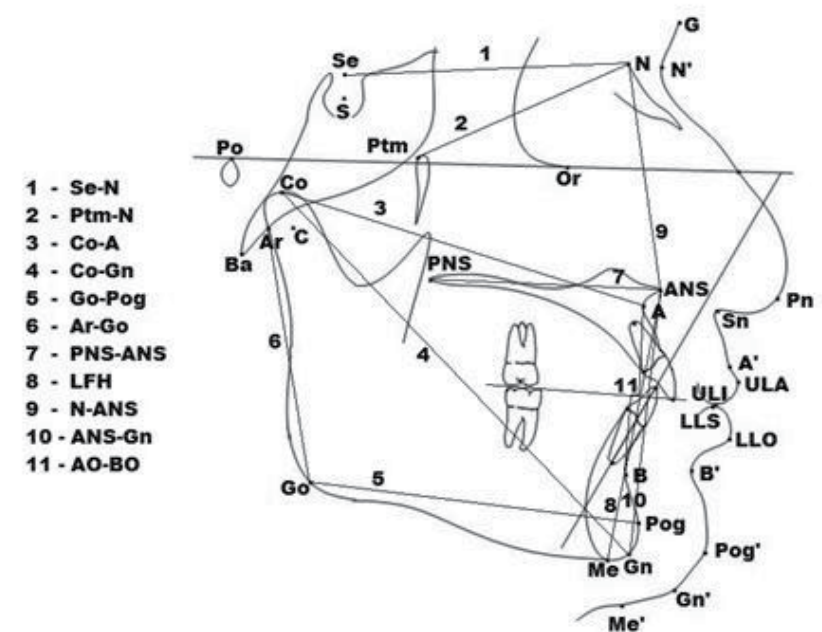

Figure 3a. Cephalometric skeletal linear measurements and definitions.

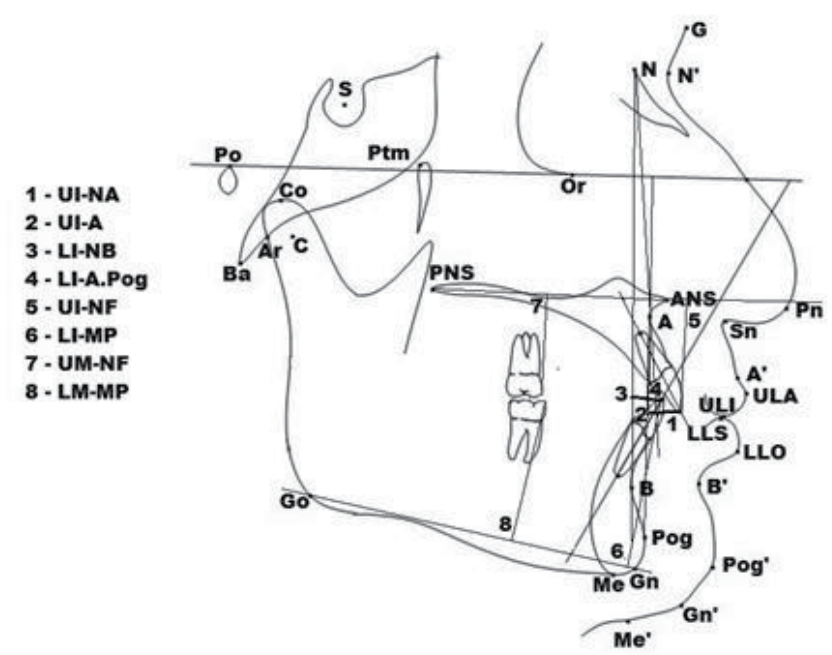

Figure 3b. Cephalometric dental linear measurements and their definitions.

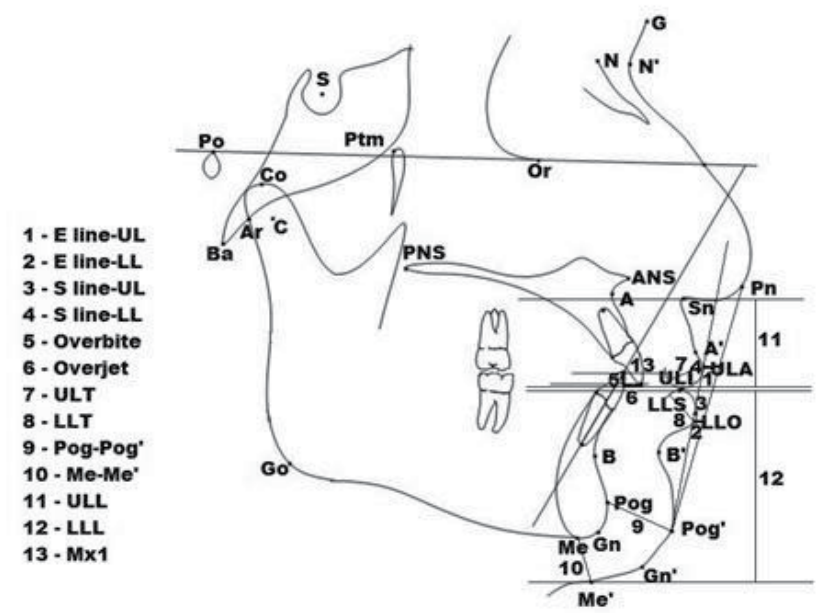

Figure 3c. Cephalometric soft tissue linear measurements and their definitions. 


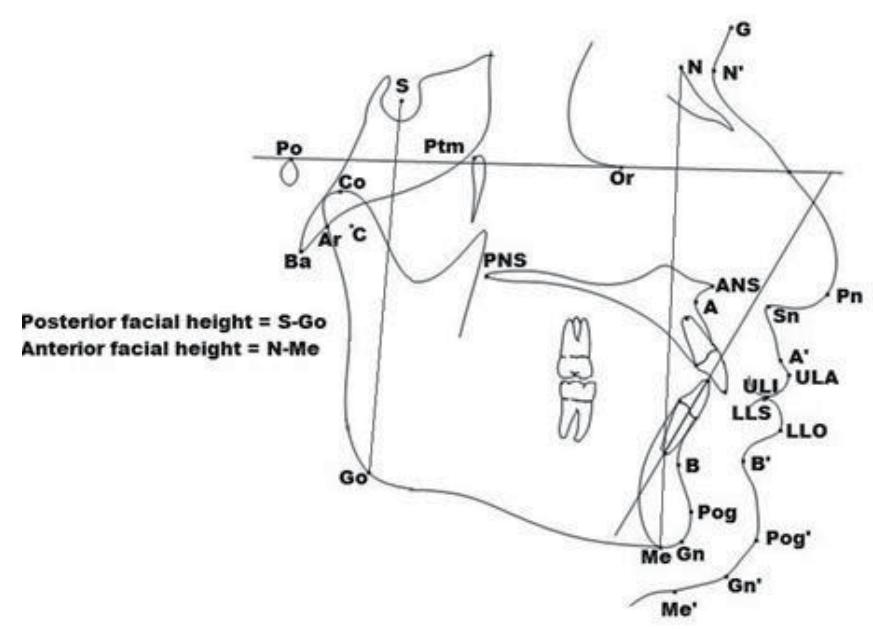

Figure 4. Cephalometric angular proportional measurements and their definitions.

it operates under several simplifying assumptions that may be incorrect, or the error may be due to sampling fluctuation and/ or environmental covariation. The following points must be kept in mind while estimating heritability. 1) It must be noted that heritability estimates do not state for sure that a certain trait is determined to a specific degree by genetic and environmental factors in a single individual. 2) These estimates are not predictive; rather they are descriptive of variances within a sample at a given time. The photographic analysis was performed for all parents and their offspring (Table 4).

\section{RESULTS}

From Dahlberg's double determination method, it is clear that the largest error between two readings (manual and digitized) was 1.112 for SNB, while the lowest was 0.438 for IMPA in angular measurements and 1.031 for $\mathrm{Mx} 1$ exposure, while the lowest was 0.514 for PNS-ANS in linear measurements. Regarding the second method; the coefficient of reliability, was 0.9 , indicating a high and positive correlation between the manual and digitized readings, therefore the results from this study can be considered valid and reliable. (Table 5, 6)

\section{Pearson's Correlation between Parents and Offspring}

Results of the correlation between parents and their offspring for the corresponding angular, linear, and proportional measurements. Statistically significant correlations for the corresponding three groups of measurements were found more often in the father-offspring groups than in the mother offspring groups. Statistically stronger correlations in angular measurements were $\left(\mathrm{SNA}^{0}, \mathrm{SNB}^{0}\right.$, FACIALAXISANGLE, UI-

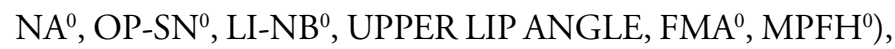
while (maxillary body length. mandibular body length, N-ANS, LI-NB, LI-A.Pog, Ar-Go, UI-pt.A, Me-Me', Pog-Pog)' were among the highest correlated linear variables. (Figure 5, 6)

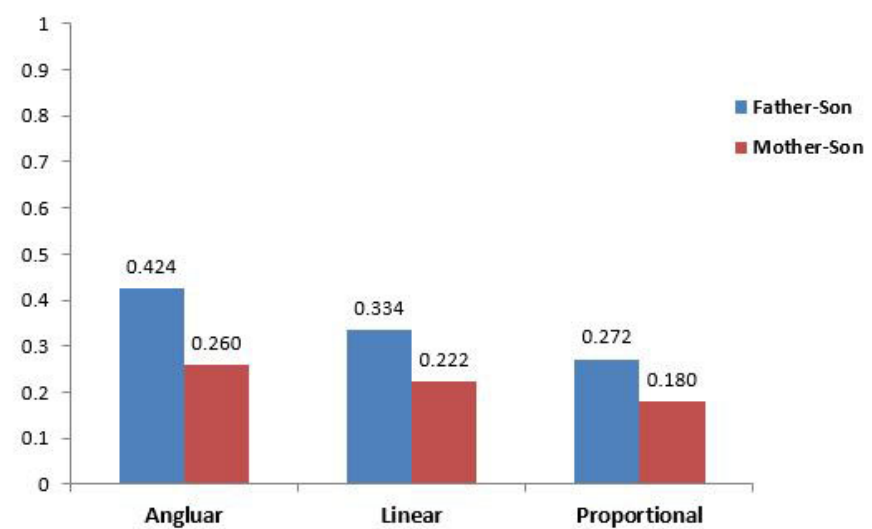

Figure 5. Overall mean values of correlation coefficients for the corresponding angular, linear and proportional measurements in sons group.

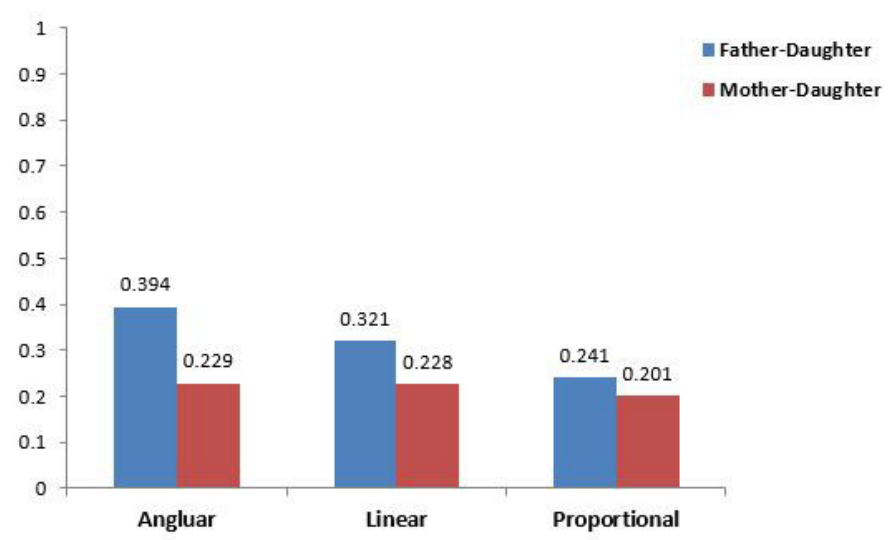

Figure 6. Overall mean values of correlation coefficients for the corresponding angular, linear and proportional measurements in daughters group.

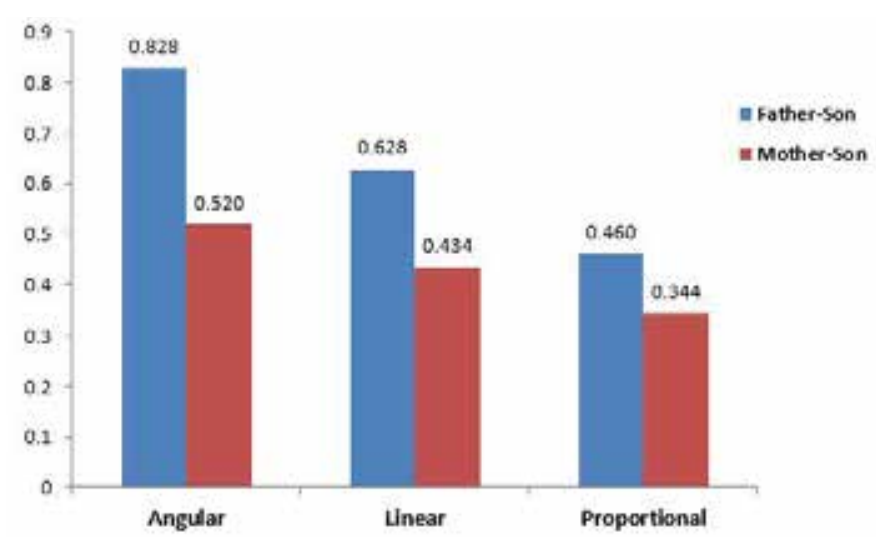

Figure 7. Overall mean values of heritability for the corresponding angular, linear and proportional measurements in sons group.

displays the mean value for each of the three measurement groups. The Figure given below shows that correlations between father-offspring were higher than correlations between motheroffspring. Stronger correlations were also found between parentsson groups than between parents-daughter. 
Table 3. Cephalometric linear measurements and their definitions.

\begin{tabular}{|c|c|c|c|}
\hline \multicolumn{3}{|r|}{ Measurement } & \multirow{2}{*}{$\begin{array}{r}\text { Definition } \\
\text { Anterior cranial base length. }\end{array}$} \\
\hline 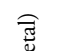 & 1. & Se-N & \\
\hline 递 & 2. & Ptm-N & Cranial base lenth . \\
\hline 丞 & 3. & Co-Pt A & Maxillary length. \\
\hline \multirow{9}{*}{ 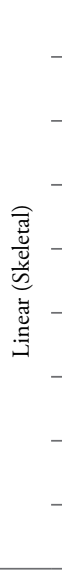 } & 4. & Co -Gn & Mandibular length. \\
\hline & 5. & PNS-ANS & Maxillary length. \\
\hline & 6. & Go-Pg & Length of mandibular body. \\
\hline & 7. & Ar-Go & Ramus height. \\
\hline & 8. & LFH & Lower anterior face height. \\
\hline & 9. & N-ANS (COGS) & Middle third facial height. \\
\hline & & ANS-Gn (COGS) & Lower third facial height. \\
\hline & & $\begin{array}{l}\text { MAXILLO MANDI } \\
\text { DIFFERENCE }\end{array}$ & Maxillary-Mandibular length difference. \\
\hline & & $\begin{array}{l}\text { AO-BO (WITTS } \\
\text { APPRAISAL) }\end{array}$ & $\begin{array}{l}\text { Distance between perpendiculars from points A and B } \\
\text { on the maxilla and mandible to occlusal plane. }\end{array}$ \\
\hline \multirow{8}{*}{ 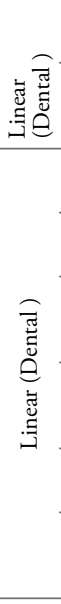 } & & $\begin{array}{l}\text { Upper Incisor to NA } \\
\text { (STEINER'S) }\end{array}$ & Linear measurement between NA line and upper incisor. \\
\hline & & $\begin{array}{l}\text { Upper Incisor to A } \\
\text { (MC NAMARA) }\end{array}$ & $\begin{array}{l}\text { A vertical line is drawn through point A parallel to } \\
\text { nasion perpendicular The distance from point A to the } \\
\text { facial surface of upper incisor. }\end{array}$ \\
\hline & & Lower Incisor to NB & Linear measurement between NB line and lower incisor. \\
\hline & & $\begin{array}{l}\text { Lower Incisor to } \\
\text { A.Pog }\end{array}$ & $\begin{array}{l}\text { Distance between the edge of mandibular incisor and } \\
\text { a line drawn from point } A \text { to pogonion. }\end{array}$ \\
\hline & & $\begin{array}{l}\text { Upper Incisor to NF } \\
\text { (COGS) }\end{array}$ & $\begin{array}{l}\text { Anterior maxillary dental height. A perpendicular is } \\
\text { dropped from incisal edge of maxillary central incisor to } \\
\text { nasal floor. }\end{array}$ \\
\hline & & $\begin{array}{l}\text { Lower Incisor to MP } \\
\quad \text { (COGS) }\end{array}$ & $\begin{array}{l}\text { Anterior mandibular dental height. A perpendicular is } \\
\text { dropped from incisal edge of mandibular central incisor } \\
\text { to mandibular plane. }\end{array}$ \\
\hline & 19. & $\begin{array}{l}\text { Upper Molar to NF } \\
\text { (COGS) }\end{array}$ & $\begin{array}{l}\text { This is perpendicular line drawn from nasal floor passing } \\
\text { through the mesiobuccul cusp tip of maxillary first molar. }\end{array}$ \\
\hline & & $\begin{array}{l}\text { Lower Molar to MP } \\
\quad \text { (COGS) }\end{array}$ & $\begin{array}{l}\text { This is perpendicular line drawn from mandibular plane } \\
\text { passing through the mesiobuccul cusp tip of mandibular } \\
\text { first molar. }\end{array}$ \\
\hline \multirow{2}{*}{ 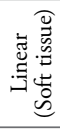 } & & E-Line upper lip & \multirow{2}{*}{$\begin{array}{l}\text { Its distance of upper and lower lip from } \mathrm{E} \text { line which is } \\
\text { drawn from tip of the nose to soft tissue pogonion. }\end{array}$} \\
\hline & & E-Line lower lip & \\
\hline \multirow{11}{*}{ 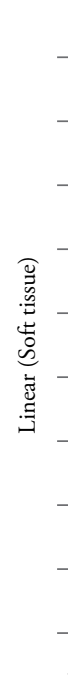 } & & S-Line upper lip & \multirow{2}{*}{$\begin{array}{l}\text { Its distance of upper and lower lip from } S \text { line which is } \\
\text { drawn from soft tissue pogonion to midpoint of S-shapec } \\
\text { curve between subnasale and nasal tip. }\end{array}$} \\
\hline & & S-Line lower lip & \\
\hline & 25. & Over jet & Horizantal distance between upper and lower incisor tip. \\
\hline & 26. & Over bite & Vertical distance between upper and lower incisor tip. \\
\hline & & Upper lip thickness & It is a distance from upper lip inside to upper lip anterior. \\
\hline & & Lower lip thickness & It is a distance from lower lip inside to lower lip out side. \\
\hline & & Pogonion Pogonion & $\begin{array}{l}\text { It is a distance from hard tissue Pogonion to soft tissue } \\
\text { Pogonion. }\end{array}$ \\
\hline & & Menton Menton & $\begin{array}{l}\text { It is a distance from hard tissue Menton to soft tissue } \\
\text { Menton. }\end{array}$ \\
\hline & & Upper lip length & $\begin{array}{l}\text { It is a distance from Subnasale to upper lip inferior } \\
\text { (stomion superius) }\end{array}$ \\
\hline & & Lower lip length & $\begin{array}{l}\text { It is a distance from lower lip superior (stomion inferius) } \\
\text { to soft tissue menton. }\end{array}$ \\
\hline & 33. & Mx1 exposure & $\begin{array}{l}\text { It is a distance from upper lip inferior (stomion superius) } \\
\text { to maxillary incisor tip. }\end{array}$ \\
\hline
\end{tabular}

\section{Table 4. Photographic analysis}

\section{Frontal view at rest}

Evaluation of facial symmetry

The face can be divided along the midsagittal plane with a symmetry line passing through glabella,nasal tip,mid point of upper lip and midpoint of chin.

three parallel lines are drawn which are perpendicular to facial midline and passing through the following threepoints.1.Glabella 2.Subnasale3.Menton

Evaluation of vertical proportion

Evaluation of lower third of the The lower third is further subdivided by passing a line
face

Evaluation of facial index Bizygomatic width x100/length of face

\begin{tabular}{ll}
\hline \multicolumn{1}{c|}{ Profile view } \\
\hline Evaluation of facial divergence & It is the angle between FH plane and facial plane. \\
\hline Evaluation of nasolabial angle & $\begin{array}{l}\text { It is the angle between a line drawn tangent to base of } \\
\text { nose and a line tangent to philtrum of the upper lip. }\end{array}$ \\
\hline Holdaway's analysis (H-Line) & $\begin{array}{l}\text { Distance of upper sulcus depth is measured from H } \\
\text { line(line tangent to the chin point and the upper lip) }\end{array}$ \\
\hline Rickett's analysis (E-Line) & $\begin{array}{l}\text { Distance of upper and lower lip is measured from E } \\
\text { line(line drawn from tip of the nose to tip of the chin. }\end{array}$
\end{tabular}

Table 5. Reliability Analysis-Manual and Digitized. Angular measurements as evaluated by Dablberg's double determination method and coefficient of reliability. All readings are in degrees.

\begin{tabular}{|c|c|c|c|}
\hline Sr. No. & $\begin{array}{l}\text { Variable } \\
\text { (Angular) }\end{array}$ & $\begin{array}{l}\text { Dahlberg's Method } \\
\text { (Coefficient) }\end{array}$ & $\begin{array}{c}\text { Coefficient } \\
\text { of Reliability }\end{array}$ \\
\hline 1 & SNA & 0.621 & 0.971 \\
\hline 2 & SNB & 1.112 & 0.982 \\
\hline 3 & FAA & 0.523 & 0.941 \\
\hline 4 & FMA & 0.654 & 0.945 \\
\hline 5 & MP-FH & 0.542 & 0.912 \\
\hline 6 & MP-SN & 0.623 & 0.955 \\
\hline 7 & ANB & 0.847 & 0.977 \\
\hline 8 & $\mathrm{BA}$ & 0.877 & 0.956 \\
\hline 9 & UI-NA angle & 0.555 & 0.943 \\
\hline 10 & UI-SN & 0.456 & 0.965 \\
\hline 11 & IMPA & 0.438 & 0.966 \\
\hline 12 & LI-NB angle & 0.577 & 0.932 \\
\hline 13 & LI-OP & 0.569 & 0.945 \\
\hline 14 & OP-FH & 0.652 & 0.944 \\
\hline 15 & OP-SN & 0.530 & 0.958 \\
\hline 16 & HLA & 0.544 & 0.987 \\
\hline 17 & $\mathrm{Z}$ & 0.588 & 0.924 \\
\hline 18 & NA & 0.688 & 0.958 \\
\hline 19 & ULA & 0.555 & 0.966 \\
\hline
\end{tabular}


Table 6. Reliability Analysis-Manual and Digitised for the Linear measurements as evaluated by Dablberg's double determination method and coefficient of reliability. All readings are in $\mathrm{mm}$.

\begin{tabular}{|c|c|c|c|}
\hline Sr. No. & $\begin{array}{l}\text { Variable } \\
\text { (Linear) }\end{array}$ & $\begin{array}{l}\text { Dahlberg's Method } \\
\text { (Coefficient) }\end{array}$ & $\begin{array}{c}\text { Coefficient } \\
\text { of Reliability }\end{array}$ \\
\hline 1 & Se-N & 0.825 & 0.970 \\
\hline 2 & Ptm-N & 0.581 & 0.950 \\
\hline 3 & Co-PtA & 0.765 & 0.963 \\
\hline 4 & PNS-ANS & 0.514 & 0.947 \\
\hline 5 & Co-Gn & 1.023 & 0.953 \\
\hline 6 & Go-Pg & 0.930 & 0.946 \\
\hline 7 & Ar-Go & 0.987 & 0.956 \\
\hline 8 & LFH & 0.843 & 0.988 \\
\hline 9 & N-ANS & 1.036 & 0.974 \\
\hline 10 & ANS-Gn & 0.825 & 0.943 \\
\hline 11 & $\mathrm{CoGn}-\mathrm{CoA}$ & 0.826 & 0.956 \\
\hline 12 & AO-BO & 0.698 & 0.954 \\
\hline 13 & UI-NA & 1.013 & 0.944 \\
\hline 14 & UI-pt.A & 0.522 & 0.960 \\
\hline 15 & LI-NB & 0.689 & 0.968 \\
\hline 16 & LI-A.Pog & 1.236 & 0.977 \\
\hline 17 & UI-NF & 0.669 & 0.980 \\
\hline 18 & LI-MP & 0.659 & 0.960 \\
\hline 19 & UM-NF & 0.741 & 0.933 \\
\hline 20 & LM-MP & 0.874 & 0.944 \\
\hline 21 & E-Line UL & 0.749 & 0.943 \\
\hline 22 & E-Line LL & 0.698 & 0.966 \\
\hline 23 & S-Line UL & 0.874 & 0.958 \\
\hline 24 & S-Line LL & 0.588 & 0.987 \\
\hline 25 & Over jet & 1.001 & 0.983 \\
\hline 26 & Over bite & 0.689 & 0.976 \\
\hline 27 & ULT & 0.746 & 0.988 \\
\hline 28 & LLT & 0.564 & 0.933 \\
\hline 29 & Pog-Pog' & 0.578 & 0.968 \\
\hline 30 & Me-Me' & 0.821 & 0.946 \\
\hline 31 & ULL & 0.640 & 0.921 \\
\hline 32 & LLL & 0.578 & 0.903 \\
\hline 33 & Mx 1 & 1.031 & 0.943 \\
\hline
\end{tabular}

\begin{tabular}{ll}
\hline LFH: Lower ant face height & CoGn - CoA: MAXILLO MANDI DIFFERENCE \\
\hline UI-pt.A: Upper Incisor TO A & LI-A.Pog: Lower Incisor to A. Pog \\
\hline UI-NF: Upper Incisor TO NF & LI-MP: Lower Incisor to MP \\
\hline UM-NF: Upper Molar to NF & LM-MP: Lower Molar to MP \\
\hline ULT: upper lip thickness & LLT: Lower lip thickness \\
\hline ULL: Upper lip length & LLL: Lower lip length \\
\hline Mx 1: Mx 1 exposure &
\end{tabular}

\section{Heritability Estimates between Parents and Offspring}

Heritability estimatesfor the corresponding angular measurements are presented in Table 7. Father-offspring h2 values were higher than those in the mother-offspring group. As can be noted, in angular measurements fewer heritability estimates such as (LINB0, OP-FH0) were found stronger in mother-offspring group. Heritability estimates for the linear measurements are presented in Table 8. linear measurements (upper lip thickness, LI-A.pog and $\mathrm{Me}-\mathrm{Me}$ ) were found stronger in mother-son group and (E line to upper lip, over bite, Mx 1 exposure) were stronger in mother-daughter group. Any estimate .1 was considered a meaningless value because heritability estimates should be between the values of 0 and 1 (Figure 7) shows that the mean h2 values for all three measurements were higher in father offspring groups than in mother-offspring groups, with the son resembling fathers more than the daughters did.

\section{Photographic analysis}

Photographic analysis showed over all less correlation, only the following measurements showed significant correlation 1. All Mothers and their offsprings (Son / Daughter) had facial symmetry.

Table 7. Listing of heritability estimates for the corresponding angular measurements and standard errors in sons groups.

\begin{tabular}{|c|c|c|c|c|c|}
\hline & & & & & \\
\hline Sr. No. & Variable & $h^{2}$ & SE & $h^{2}$ & SE \\
\hline 1 & SNA & $0.944^{*}$ & 0.235 & 0.846 & 0.236 \\
\hline 2 & SNB & 0.802 & 0.275 & 0.376 & 0.285 \\
\hline 3 & FAA & •1.348*** & 0.258 & 0.374 & 0.219 \\
\hline 4 & FMA & 0.806 & 0.209 & 0.716 & 0.198 \\
\hline 5 & MP-FH & 0.636 & 0.211 & 0.660 & 0.212 \\
\hline 6 & MP-SN & 0.830 & 0.239 & 0.212 & 0.195 \\
\hline 7 & ANB & $\bullet 1.054^{*}$ & 0.224 & 0.728 & 0.147 \\
\hline 8 & BA & •1.090* & 0.193 & 0.828 & 0.147 \\
\hline 9 & UI-NA angle & $0.984^{*}$ & 0.381 & 0.816 & 0.274 \\
\hline 10 & UI-SN & 0.578 & 0.354 & 0.370 & 0.247 \\
\hline 11 & IMPA & 0.594 & 0.275 & 0.688 & 0.346 \\
\hline 12 & LI-NB angle & 0.658 & 0.290 & 0.662 & 0.344 \\
\hline 13 & LI-OP & 0.744 & 0.440 & 0.156 & 0.478 \\
\hline 14 & OP-FH & 0.750 & 0.301 & 0.784 & 0.330 \\
\hline 15 & OP-SN & $0.952^{*}$ & 0.250 & 0.208 & 0.292 \\
\hline 16 & HLA & 0.360 & 0.270 & 0.180 & 0.259 \\
\hline 17 & Z & 0.680 & 0.217 & 0.452 & 0.305 \\
\hline 18 & NA & 0.746 & 0.295 & 0.680 & 0.161 \\
\hline 19 & ULA & 0.470 & 0.250 & 0.530 & 0.199 \\
\hline$h^{2}$ : Herital & ility Coefficient & & 0.01 & & \\
\hline SE: Stand & rd Error & & 0.001 & & \\
\hline${ }^{*} \mathrm{P} \leq 0.05$ & & & ningless & & \\
\hline
\end{tabular}


Table 8. Listing of heritability estimates for the corresponding linear measurements \& standard errors in sons groups.

\begin{tabular}{|c|c|c|c|c|c|}
\hline \multirow[b]{2}{*}{ Sr. No. } & \multirow[b]{2}{*}{ Variable } & \multicolumn{2}{|c|}{ FATHER } & \multicolumn{2}{|c|}{ MOTHER } \\
\hline & & $h^{2}$ & SE & $h^{2}$ & SE \\
\hline 1 & Se-N & 0.862 & 0.216 & 0.200 & 0.173 \\
\hline 2 & Ptm-N & 0.706 & 0.226 & 0.634 & 0.220 \\
\hline 3 & Co-PtA & 0.872 & 0.177 & $0.960^{*}$ & 0.175 \\
\hline 4 & PNS-ANS & 0.734 & 0.211 & 0.790 & 0.171 \\
\hline 5 & Co-Gn & •1.016* & 0.194 & $0.872^{*}$ & 0.202 \\
\hline 6 & Go-Pg & 0.784 & 0.152 & 0.740 & 0.142 \\
\hline 7 & Ar-Go & 0.100 & 0.141 & 0.500 & 0.141 \\
\hline 8 & LFH & 0.602 & 0.352 & 0.106 & 0.372 \\
\hline 9 & N-ANS & $\cdot 1.080^{*}$ & 0.361 & 0.334 & 0.277 \\
\hline 10 & ANS-Gn & 0.588 & 0.341 & 0.120 & 0.341 \\
\hline 11 & CoGn - CoA & 0.446 & 0.383 & 0.260 & 0.276 \\
\hline 12 & AO-BO & 0.624 & 0.314 & 0.410 & 0.183 \\
\hline 13 & UI-NA & $0.876^{*}$ & 0.280 & 0.730 & 0.227 \\
\hline 14 & UI-pt.A & 0.694 & 0.411 & 0.456 & 0.310 \\
\hline 15 & LI-NB & 0.740 & 0.393 & $\bullet 1.124^{*}$ & 0.278 \\
\hline 16 & LI-A.Pog & 0.596 & 0.409 & $0.914^{*}$ & 0.401 \\
\hline 17 & UI-NF & 0.690 & 0.266 & 0.036 & 0.268 \\
\hline 18 & LI-MP & 0.308 & 0.280 & 0.252 & 0.329 \\
\hline 19 & UM-NF & 0.596 & 0.329 & 0.302 & 0.475 \\
\hline 20 & LM-MP & 0.748 & 0.056 & 0.246 & 0.053 \\
\hline 21 & E-Line UL & 0.686 & 0.310 & 0.554 & 0.260 \\
\hline 22 & E-Line LL & 0.670 & 0.225 & 0.590 & 0.273 \\
\hline 23 & S-Line UL & 0.386 & 0.296 & 0.124 & 0.369 \\
\hline 24 & S-Line LL & 0.766 & 0.153 & 0.728 & 0.209 \\
\hline 25 & Over jet & 0.490 & 0.199 & 0.476 & 0.204 \\
\hline 26 & Over bite & 0.460 & 0.154 & 0.128 & 0.200 \\
\hline 27 & ULT & 0.462 & 0.245 & 0.488 & 0.239 \\
\hline 28 & LLT & 0.490 & 0.265 & 0.174 & 0.304 \\
\hline 29 & Pog-Pog' & 0.726 & 0.190 & 0.548 & 0.175 \\
\hline 30 & Me-Me' & 0.404 & 0.359 & 0.464 & 0.303 \\
\hline 31 & ULL & 0.660 & 0.391 & 0.118 & 0.276 \\
\hline 32 & LLL & 0.754 & 0.241 & 0.104 & 0.193 \\
\hline 33 & Mx 1 & 0.130 & 0.173 & 0.062 & 0.162 \\
\hline \multicolumn{2}{|c|}{$\mathrm{h}^{2}:$ Heritability Coefficient } & \multicolumn{2}{|c|}{${ }^{* *} \mathrm{P} \leq 0.01$} & & \\
\hline \multicolumn{2}{|c|}{ SE: Standard Error } & \multicolumn{2}{|c|}{$* * * \mathrm{P} \leq 0.001$} & & \\
\hline \multicolumn{2}{|l|}{${ }^{* P} \leq 0.05$} & \multicolumn{3}{|c|}{ - Meaningless value } & \\
\hline
\end{tabular}

2. Father's Glabella point to Subnasale point length significantly correlated with sons Glabella point to Subnasale point length.

3. Father's facial index significantly associated with son's facial index.

4. Father's upper one-third of lower facial third length significantly correlated with son's upper one-third facial length.

5. Mother's nasobial angle significantly correlated with son's nasobial angle.

\section{DISCUSSION}

Heritability, in a restricted sense, is acquired from the parentoffspring correlation and expresses the proportion of the total phenotypic that has come up with additive genetic variance, the genotype. This additive constituents is what determines the degree of similarity between relatives representing the part of genetic variance that can be used to anticipate the expected measurement value in an individual from relatives' observation. ${ }^{9}$ The aim of this study was to assess the similarity of several cephalometric craniofacial variables and facial photographic features between Indian parents and their offspring. The duration of the offspring was chosen to be post-pubertal so as to keep down the effect of variations related to timing and rate of growth. Formerly reported research included different offspring ages when compared with their parents, which started as early as 4 years in a study by Harris and Johnson $(1991)^{10}$ and 6 years of age by Ichinose et al $(1993)^{11}$ and Johannsdottir et al $(2005)^{12}$.

Hunter et al in $1970{ }^{13}$ mentioned high up and more statistically significant correlations with his post-pubertal offspring study from an earlier series of studies peruse the dentofacial relationships between parents and growing offspring. Other longitudinal heredity studies revealed increasing heritability values for skeletal craniofacial characteristics with increasing age (Suzuki and Takahama $(1988)^{14}$, Ichinose et al $(1993)^{11}$ and Johannsdottir et al (2005). ${ }^{12}$

Regarding the second method; the coefficient of reliability, was 0.9 , suggesting a high and positive correlation between the manual and digitized readings. Therefore the results from this study can be considered valid and reliable (Baumrind and Frantz 1971, Houston 1983). ${ }^{17,27}$

In the current study the most observable feature was stronger correlations and $\mathrm{h} 2$ values between the fathers and their offsprings for corresponding skeletal, dental and soft tissue measurements, with higher correlation in skeletal measurements. This may be attributed to a less maternal effect from the mother. This feature was in agreement with Hunter et al $(1970)^{13}$ and Nakata et al $(1973)^{18}$. However, it did not support the results of both Saunders et al $(1980)^{19}$ and Nakisama et al $(1986)^{20}$ where they found no statistically significant dissimilarity in the number of any parent offspring correlations.

From the values obtained in this study added significant 
correlations and stronger heritability in the father-son pairings were found for the corresponding craniofacial variables. Hunter et al $(1970)^{13}$ and Saunders et al $(1980)^{19}$ found no significant differences between sons and daughters correlations to their parents, while studies such as Suzuki and Takahama's (1988) ${ }^{14}$, Ichinose et al $(1993)^{11}$ and Johannsdottir et al $(2005)^{12}$ found that daughters were more afflicted by their parents than sons.

In the present study, angular computation had higher heritability estimates than linear variables in all parent-offspring pairings excluding the mother-daughter group. This was in agreement with Nakata et al $(1973)^{18}$ that the high heritability establish in twins for the angular measurements.

The current studies clearly showed over all mean heritability estimates are stronger in father offspring groups for the corresponding angular, linear, proportional measurements. In angular measurements fewer $\mathrm{h} 2$ values such as lower incisor to NB (LI-NB)0 an Op-FH0 were found stronger in motheroffspring groups. In linear measurements $\mathrm{h} 2$ values such as upper lip thickness, Me-Me' and Lower incisor to A.Pog (LI-A.Pog) were found stronger in mother-son groups and $\mathrm{E}$ line to upper lip, over bite and $\mathrm{Mx} 1$ exposure were found stronger in mother daughter groups. $\mathrm{SNA}^{\circ}$ had relatively powerful significant correlation in the father-offspring than the mother offspring cluster. $\mathrm{SNB}^{\circ}$ was found to have significant correlation in father-daughter pairings. $\mathrm{ANB}^{\circ}$ was only significantly correlated in the father-son pairings which was supported by Saunders et al (1980) ${ }^{19}$ study. Facial axis angle showed correlation in father-son group. The mandibular angular measurements such as FMA0 and MP-FH0 showed high correlation in mother-daughter groups.

In dental angular cephalometric measurements upper incisor to NA (UI-NA)0 found to show significant correlation in fatherson pairings and OP-SN0 showed correlation in father-offspring group. Lower incisor to NB (LI-NB)0 showed significant correlation in mother-son group. The low heritability of the dental parameters demonstrates strong environmental impact regarding tooth position. This stipulate that lips, tongue, cheeks, breathing, mastication, nutrition, neuromuscular interaction, and par functional activities might play dominant roles in the development of tooth position and the occlusion. Our outcome comply with those of Saunders et al ${ }^{19}$, Lundstöm and McWilliam ${ }^{21}$, and Ichinose et $\mathrm{al}^{11}$, who all noted low heritability of dentoalveolar variables. Bondevik $(1998)^{22}$ evaluated significant age related occlusal changes in adult dentition.

Upper lip angle in soft tissue angular cephalometric measurements found to show significant correlation in father-daughter groups. Maxillary length Co-Pt. A was amid the highest correlations found in this study, except in mother-daughter groups. Mandibular length (Co-Gn) showed significant correlation in parents-son groups. Ramus length showed correlation in parent daughter groups. Anterior facial height dimension N-ANS correlations found in the father-son pairings. Me-Me' in soft tissue linear measurements showed similarity in parents-daughter pairings and Pog-Pog' showed correlation in mother-daughter groups. Lower incisor to A.Pog (LI-A.Pog) and lower incisor to NB (LINB) showed similarity in mother-son groups and upper incisor to A (UIA) correlated in father-daughter groups.

In the present study comparing the outcome photographic analysis between parents and off springs indicated that Vertical facial proportions showed significant correlation between father son groups. Father's facial index significantly associated with son's facial index and mother's nasolabial angle significantly correlated with son's nasolabial angle. In this research, vertical facial measurements had generally moderate heritability values, on the contrary soft-tissues, except nasolabial angle did not show significant correlation.

These data specify that the genetic ascertainment is significantly low in the soft-tissue measurements. These findings proof that craniofacial morphology is the result of a complex interaction between inheritance and environmental elements and is, therefore multifarious.

Torlakovic et al (2011) ${ }^{24}$ concluded that noteworthy changes happen occur in soft tissue facial profile from second to fourth decennium. Waning of the male facial profile start 10 years after than for females; however, when the transform did occur, they were of greater magnitude. The upper facial profile was moved in the forward direction and the whole profile was moved inferiorly for both sexes.

It has been mentioned previously (Savoye et al 1998) ${ }^{25}$ that variables with a low heritability could be more easily altered with environmental intervention, than those with a higher and stronger heritability background. However, that does not mean that environment cannot change the genetically determined variables. It is important to investigate the origin of a disorder, and it must be put in mind that the reaction to environmental intervention depends more on the response of each individual which is due to their genetic background, in other words the individual's genetic susceptibility. This genetic-environmental interaction may explain why a particular treatment modality is successful in some patients and not in others.

\section{CONCLUSION}

The results of the present study demonstrated the following:

1. Various cephalometric craniofacial characteristics and photographic features have correlations and heritability between interfamilial parent-offspring groups.

2. Stronger correlations and heritability estimates were found between the Indian fathers and their offspring for corresponding skeletal, dental and soft tissue measurements, with higher correlation in skeletal measurements. 
3. Added noteworthy correlations and stronger heritability in the father-son pairings.

4. Over all mean heritability estimates are stronger in fatheroffspring groups for the corresponding angular, linear, proportional measurements; angular measurements had higher heritability assessment than linear variables in all parentoffspring pairings excluding the mother-daughter group.
5. These interfamilial correlations and heritability should be considered during orthodontic case diagnosis, analysis and treatment planning to have more predictable treatment out comes and to minimize the problem of relapse.

\section{CONFLICT OF INTEREST}

The authors of the present article declare no conflicts of interest.

\section{REFERENCES}

1. Mossey PA. The heritability of malocclusion: Part 1--Genetics, principles and terminology. Br J Orthod. 1999;26(2):103-113.

2. van der Linden FP. Genetic and environmental factors in dentofacial morphology. Am J Orthod. 1966;52(8):576-583.

3. Mossey PA. The heritability of malocclusion: part 2. The influence of genetics in malocclusion. Br J Orthod. 1999;26(3):195-203.

4. Alkhudhairi TD, Alkofide EA. Cephalometric craniofacial features in Saudi parents and their offspring. Angle Orthod. 2010;80(6):1010-1017.

5. McKeown HF, Murray AM, Sandler PJ. How to avoid common errors in clinical photography. J Orthod. 2005;32(1):43-54.

6. Solow B, Tallgren A. Natural head position in standing subjects. Acta Odontol Scand. 1971;29(5):591-607.

7. Jacobson A, Jacobson RL. Radiographic Cephalometry:From Basics to 3-D Imaging. 2nd ed. Chicago, Ill:Quintessence Publishing; 2006.

8. Rakosi T, Jonas I, Graber T Orthodontic Diagnosis, Georg Thieme Ver, Orthodontic diagnosis: color atlas of dental medicine; 1993.

9. LaBuda MC, Gottesman II, Pauls DL. Usefulness of twin studies for exploring the etiology of childhood and adolescent psychiatric disorders. Am J Med Genet. 1993;48(1):47-59.

10. Harris EF, Johnson MG. Heritability of craniometric and occlusal variables: a longitudinal sib analysis. Am J Orthod Dentofacial Orthop. 1991;99(3):258-268.

11. Ichinose M, Nakasima A, Hu JR. Growth-related changes in familial resemblance of maxillofacial morphology. J Craniofac Genet Dev Biol. 1993;13(1):35-46.

12. Johannsdottir B, Thorarinsson F, Thordarson A, Magnusson TE. Heritability of craniofacial characteristics between parents and offspring estimated from lateral cephalograms. Am J Orthod Dentofacial Orthop. 2005;127(2):200-261.

13. Hunter WS, Balbach DR, Lamphiear DE. The heritability of attained growth in the human face. Am J Orthod. 1970;58(2):128-134.

14. Suzuki A, Takahama Y. A cephalometric study on the similarity of craniofacial morphology between children and their parents. J Jpn Orthod Soc. 1988; 47:697719. (Japanese)

15. Cole JB, Manyama M, Larson JR, et al. Human Facial Shape and Size Heritability and Genetic Correlations. Genetics. 2017;205(2):967-978.

16. Kim E, Sung J, Song YM, et al. Heritability of Facial Skeletal and Dental Characteristics of Monozygotic and Dizygotic Twins Using Cephalometric Analysis and Falconer's Method. J Craniofac Surg. 2018;29(3):e274-e279.

17. Baumrind S, Frantz RC. The reliability of head film measurements. 2. Conventional angular and linear measures. Am J Orthod. 1971;60(5):505-517.

18. Nakata N, Yu PI, Davis B, Nance WE. The use of genetic data in the prediction of craniofacial dimensions. Am J Orthod. 1973;63(5):471-480.
19. Saunders SR, Popovich F, Thompson GW. A family study of craniofacial dimensions in the Burlington Growth Centre sample. Am J Orthod. 1980;78(4):394-403.

20. Nakasima A, Ichinose M, Nakata S. Genetic and environmental factors in the development of so-called pseudo- and true mesiocclusions. Am J Orthod Dentofacial Orthop. 1986;90(2):106-116.

21. Lundström A, McWilliam J. The influence of heredity and environment on six variables describing incisor orientation. Eur J Orthod. 1986;8(4):259-264.

22. Bondevik O. Changes in occlusion between 23 and 34 years. Angle Orthod. 1998;68(1):75-80

23. Bondevik O. Growth changes in the cranial base and the face: a longitudinal cephalometric study of linear and angular changes in adult Norwegians. Eur J Orthod 1995;17(6):525-532.

24. Torlakovic L, Faerøvig E. Age-related changes of the soft tissue profile from the second to the fourth decades of life. Angle Orthod. 2011;81(1):50-57.

25. Savoye I, Loos R, Carels C, Derom C, Vlietinck R. A genetic study of anteroposterior and vertical facial proportions using model-fitting. Angle Orthod. 1998;68(5):467470.

26. Bergersen EO. Enlargement and distortion in cephalometric radiography: compensation tables for linear measurements. Angle Orthod. 1980;50(3):230-244.

27. Houston WJB. The analysis of errors in orthodontic measurements. Am J Houston WJ. The analysis of errors in orthodontic measurements. Am J Orthod. 1983;83(5):382-390.

28. Dahlberg A. Statistical methods for medical and biological students. New York interscience publications; 1940 .

29. Tiro A, Dzemidzic V, Salaga-Nefic S, Redzic I, Nakas E. Heritability of Craniofacial Characteristics in Twins - Cephalometric Study. Med Arch. 2019;73(3):205-208.

30. Hoskens H, Li J, Indencleef K, et al. Spatially Dense 3D Facial Heritability and Modules of Co-heritability in a Father-Offspring Design. Front Genet. 2018;9:554.

31. Weinberg SM, Parsons TE, Marazita ML, Maher BS. Heritability of Face Shape in Twins: A Preliminary Study using 3D Stereophotogrammetry and Geometric Morphometrics. Dent 3000. 2013;1(1):14.

32. Djordjevic J, Jadallah M, Zhurov AI, Toma AM, Richmond S. Three-dimensional analysis of facial shape and symmetry in twins using laser surface scanning. Orthod Craniofac Res. 2013;16(3):146-160

33. Perinetti G. StaTips Part IV: Selection, interpretation and reporting of the intraclass correlation coefficient. South Eur J Orthod Dentofac Res. 2018;5(1):3-5.

34. Boyd A, Golding J, Macleod J, et al. Cohort Profile: the 'children of the 90s'--the index offspring of the Avon Longitudinal Study of Parents and Children. Int J Epidemiol. 2013;42(1):111-127. 